\title{
Procedure Dose
}

National Cancer Institute

\section{Source}

National Cancer Institute. Procedure Dose. NCI Thesaurus. Code C117518.

The amount of substance that the patient or test subject was administered during the procedure, or the total quantity administered. 